\title{
Application of Mental Nursing Care on Mr. A With Self-Concept Disorders: Low Self-Esteem
}

\author{
Sry Nofita Sari Hutagalung \\ srynofita99@gmail.com
}

\section{BAB 1 \\ PENDAHULUAN}

\subsection{Latar Belakang}

Skizofrenia merpakan gangguan mental yang ditandai dengan gangguan proses berpikir dan respons emosional yang lemah. Situasi ini umumnya merupakan jalan yang kacau balau berbicara dan berpikir, dan disertai dengan disfungsi sosial dan pekerjaan yang signifikan. Gejala awal biasanya muncul pada masa dewasa muda. Salah satu yang negatif. Gejala skizofrenia adalah harga diri yang rendah (Pardede, Keliat, \& Yulia, 2020). Skizofrenia dapat juga diartikan sebagai sekelompok reaksi psikotik yang memengaruhi berbagai area fungsi individu, termasuk dalam berpikir, berkomunikasi, menerima, menginterpretasikan realitas, merasakan dan menunjukkan emosi.Skizofrenia juga disebut sebagai penyakit kronis, parah, dan melumpuhkan, gangguan otak yang ditandai dengan pikiran kacau, waham, halusinasi, dan perilaku aneh (Pardede, Keliat, \& Yulia, 2015).

Berdasarkan data dari (WHO, 2013) ada sekitar 450 juta orang di dunia yang mengalami gangguan jiwa, sebagian besar mengalami skizofrenia, Estimasi jumlah penderita skizofrenia. Di Indonesia mencapai sekitar 400.000 oang atau sebanyak 1,7 per 1.000 penduduk. Riskesdas 2013, sedangkan Riskesdas 2018 juga menyebutkan sebanyak 84,9\% pengidap skizofrenia/ psikosis di Indonesia telah berobat. Data dari 33 Rumah sakit jiwa yang ada di seluruh Indonesia menyebutkan hingga kini jumlah penderita gangguan jiwa berat 
mencapai 2,5 juta orang. Di Provinsi Sumatera Utara sendiri penderita skizofrenia menduduki peringkat ke 21 dengan nilai privalensi $6,3 \%$ (Kemenkes, 2019).

Skizofrenia menimbulkan distorsi persepsi, emosi, dan tingkah laku sehingga pasien dengan skizofrenia memiliki risiko lebih tinggi berperilaku agresif dimana perubahan perilaku secara dramatis terjadi dalam beberapa hari atau minggu. Pasien skizofrenia sering dikaitkan dengan gangguan konsep diri harga diri rendah. Ada beberapa faktor yang menyebabkan harga diri rendah yaitu faktor predisposisi adalah penolakan orang tua yang tidak realistis, kegagagalan berulang kali, kurang mempunyai tanggung jawab personal, ketergantungan pada orang lain, ideal diri yang tidak realistis. Sedangkan faktor presipitasi terjadinya harga diri rendah adalah hilangnya sebagian anggota tubuh, berubahnya penampilan atau bentuk tubuh, mengalami kegagalan, serta menurunnya produktivitas. Hal inilah yang membuat perlunya bantuan keluarga pasien untuk merawat dan memberikan perhatian khusus pada pasien skizofrenia (Pardede., Harjuliska, \& Ramadia, 2021). Menurut Septina (berdasarkan data Rumah Sakit Jiwa daerah Surakarta (RSJD) pada tahun 2016 sampai januari 2017 terdapat pasien yang mengalami Gangguan Jiwa Konsep Diri : Harga Diri Rendah sebanyak 2520 pasien pada tahun 2016 dan 334 pasien pada bulan januari 2017.

Harga diri rendah merupakan perasaan tidak berharga,tidak berarti dan rendah diri yang berkepanjangan akibat evaluasi yang negatif terhadap diri sendiri atau kemampuan diri. Adanya perasaan hilang kepercayaan diri, merasa gagal karena tidak mampu mencapai keinginan sesuai ideal diri (Wandono, 2017). Harga diri yang rendah menyebabkan perasaan hampa dan terpisah dari orang lain dan terkadang menyebabkan depresi, kecemasan, atau kecemasan berkepanjangan. Dengan gangguan harga diri rendah bisa menyebabkan individu memiliki mood dan ingatan negatif sehingga individu tersebut lebih rawan menghadapi depresi saat menghadapi stress karena pola pikir yang ia miliki terhadap dirinya sendiri kurang baik, tujuan hidup tidak jelas, memiliki 
masa depan yang lebih pesimis, semakin rendah harga diri, semakin beresiko gangguan kepribadian (Sitanggang, Pardede, Damanik, \& Simanullang, 2020).

Salah satu cara untuk mengontrol perilaku hilangnya rasa percaya diri dari pasien harga diri rendah yaitu dengan memberi asuhan keperawatan jiwa. Pemberian intervensi keperawatan jiwa pada pasien dengan harga diri rendah berfokus pada membina hubungan saling percaya, memberi kegiatan sesuai dengan kemampuan klien, meningkatkan kontak dengan orang lain, mendorong klien mengungkapkan pikiran dan perasaan serta membantu melihat prestasi, kemampuan dan harapan klien. Survei awal pada pembuatan asuhan keperawatan jiwa pada skizofrenia ini dilakukan di Yayasan Pemenang Jiwa Sumatera dengan jumlah pasien 70 orang tetapi yang menjadi subjek didalam pembuatan asuhan keperawatan jiwa ini adalah 1 orang dengan pasien gangguan konsep diri: harga diri rendah berinisial Tn. A.

\subsection{Rumusan Masalah}

Berdasarkan masalah yang telah dipaparkan pada latar belakang maka rumusan masalah dalam masalah askep ini yaitu : Asuhan Keperawatan Jiwa Pada Tn. A Dengan Gangguan Konsep Diri: Harga Diri Rendah Di Yayasan Pemenang Jiwa Sumatera.

\subsection{Tujuan}

\subsubsection{Tujuan Umum}

Mahasiswa mampu memberikan asuhan keperawatan jiwa kepada Tn.A dengan gangguan Konsep Diri: Harga Diri Rendah

\subsubsection{Tujuan Khusus}

1. Mahasiswa mampu memahami Pengertian, tanda dan gejala, etiologi, klasifikasi, dan penatalaksanaan dan gangguan Harga Diri Rendah

2. Mahasiswa mampu melakukan pengkajian pada Tn.A dengan 
gangguan konsep diri: Harga Diri Rendah

3. Mahasiswa mampu menegakkan diagnosa keperawatan yang ada pada Tn.A dengan gangguan konsep diri: Harga Diri Rendah

4. Mahasiswa menetapkan perencanaan keperawatan pada Tn.A dengan gangguan konsep diri: Harga Diri Rendah

5. Mahasiswa melakukan implementasi keperawatan pada Tn.A dengan gangguan konsep diri : Harga Diri Rendah

6. Mahasiswa mampu mengevaluasi asuhan keperawatan pada Tn. A dengan gangguan konsep diri Harga Diri Rendah

\subsection{Manfaat}

1. Pasien

Diharapkan tindakan yang telah di ajarkan dapat di terapkan secara mandiri untuk meningkakan rasa percaya diri dan untuk mendukung kelangsungan kesehatan pasien.

2. Yayasan Pemenang Jiwa Sumatera.

Diharapkan dapat menjadi acuan dalam menanganin atau dalam memberikan pelayanan kepada pasien dengan gangguan jiwa dengan Harga Diri Rendah di Yayasan Pemenang Jiwa Sumatera. 


\section{BAB 2}

\section{TINJAUAN TEORITIS}

\subsection{Defenisi}

Harga diri adalah penilaian individu terhadap hasil yang dicapai dengan menganalisa seberapa jauh perilaku memenuhi ideal dirinya. Dapat diartikan bahwa harga diri menggambarkan sejauhmana individu tersebut menilai dirinya sebagai orang yang memeiliki kemampuan, keberartian, berharga, dan kompeten (Muhith, 2015). Menurut (Keliat, 2014), harga diri rendah adalah perasaan tidak berharga, tidak berarti dan rendah diri yang berkepanjangan akibat evaluasi negatif terhadap diri sendiri dan kemampuan diri.

Menurut (Pardede, Keliat \& Yulia, 2020), harga diri rendah adalah disfungsi psikologis yang meluas - terlepas dari spesifiknya. Masalahnya, hampir semua pasien menyatakan bahwa mereka ingin memiliki harga diri yang lebih baik. Jika kita hanya mengurangi harga diri rendah, banyak masalah psikologis akan berkurang atau hilang secara substansial sepenuhnya.

Harga diri rendah merupakan kunci penting dimana yakin terhadap kemampuannya dalam melakukan suatu perilaku dalam memperoleh hasil yang diinginkan. Memiliki self-efficacy yang tinggi cenderung memiliki kenyakinan dan kemampuan untuk memperoleh suatu tujuan (Pardede, Ariyo \& Purba, 2020). Jika dihadapkan dengan yang sulit maka dibutuhkan kepercayaan dan kemampuan keluarga serta tindakan yang tepat untuk merawat anggota keluarga yang sakit (Pardede, Harjuliska, \& Ramadia, 2021).

\subsection{Klasifikasi}

Menurut Pardede, Keliat, \& Yulia (2020), klasifikasi harga diri rendah dibagi menjadi 2 jenis, yaitu : 
1. Harga Diri Rendah Situsion aladalah keadaan dimana individu yangsebelumnya memilki harga diri positif mengalami perasaan negatif mengenai diri dalam berespon, terhadap suatu kejadian (kehilangan, perubahan)

2. Harga Diri Rendah Kronik adalah keadaan dimana individu mengalami evaluasi diri yang negatif mengenai diri atau kemampuan dalam waktu lama.

\subsection{Tanda dan Gejala}

Berikut ini adalah tanda dan gejala harga diri rendah menurut Keliat (2014), yaitu :

1. Mengkritik diri sendiri

2. Perasaan tidak mampu

3. Apatis, ekspresi sedih, afek tumpul

4. Menghindar dari orang lain (menyendiri)

5. Komunikasi kurang/tidak ada. Klien tidak tampak bercakap-cakap dengan klien lain/perawat

6. Tidak ada kontak mata, klien sering menunduk, pandangan hidup yang pesimis

7. Berdiam diri di kamar/klien kurang mobilitas atau penurunan produktivitas

8. Menolak berhubungan dengan orang lain, klien memutuskan percakapan atau pergi jika diajak bercakap-cakap dan penolakan terhadap kemampuan sendiri

9. Tidak/ jarang melakukan kegiatan sehari-hari

\subsection{Etiologi}

Berbagai faktor menunjang terjadinya perubahan dalam konsep diri seseorang menurut (Muhith, 2015) 


\section{Faktor predisposisi}

Ada beberapa faktor predisposisi yang menyebabkan Harga Diri Rendah yaitu:

1) Perkembangan individu yang meliputi :

a) Adanya penolakan dari orang tua, sehingga anak merasa tidak dicintai kemudian dampaknya anak gagal mencintai dirinya dan akan gagal pula untuk mencintaui orang lain.

b) Kurangnya pujian dan kurangnya pengakuan dari orang-orang tuanya atau orang tua yang penting/dekat individu yang bersangkutan.

c) Sikap orang tua protekting, anak merasa tidak berguna, orang tua atau orang terdekat sering mengkritik sering merevidasikan individu.

d) Anak menjadi frustasi, putus asa merasa tidak berguna dan merasa rendah diri.

2) Ideal diri

a) Individu selalu dituntut untuk berhasil.

b) Tidak mempunyai hak untuk gagal dan berbuat salah.

c) Anak dapat menghakimi dirinya sendiri dan hilangnya rasa percaya diri.

\section{Faktor presipitasi}

Faktor presipitasi atau stressor pencetus dari munculnya Harga Diri Rendah menurut (Pardede, Keliat \& Yulia, 2020), mungkin ditimbulkan dari sumber internal dan eksternalseperti:

1) Gangguan fisik dan mental salah satu anggota keluarga sehingga keluarga merasa malu dan rendah diri.

2) Pengalaman traumatik berulang seperti penganiayaan seksual dan psikologis atau menyaksikan kejadian yang mengancam kehidupan, aniaya fisik, kecelakaan, bencana alam dalam perampokan. Respon terhadap trauma pada umunya akan 
mengubah arti trauma tersebut dan kopingnya adalah represi dan denial.

3. Perilaku

1) Dalam melakukan pengkajian, Perawat dapat memulai dengan mengobservasi penampilan Klien, misalnya kebersihan, dandanan, pakaian. Kemudian Perawat mendiskusikannya dengan Klien untuk mendapatkan pandangan Klien tentang gambaran dirinya.

2) Perilaku berhubungan dengan Harga Diri Rendah. Harga Diri yang Rendah merupakan masalah bagi banyak orang dan mengekspresikan melalui tingkat kecemasan yang sedang sampai berat. Umumnya disertai oleh evaluasi diri yang negatif membenci diri sendiri dan menolak diri sendiri (Pardede, Keliat, \& Yulia, 2015).

4. Rentang Respon

Tabel 2.1 Rentang Respon Harga Diri Rendah (Muhith, 2015)

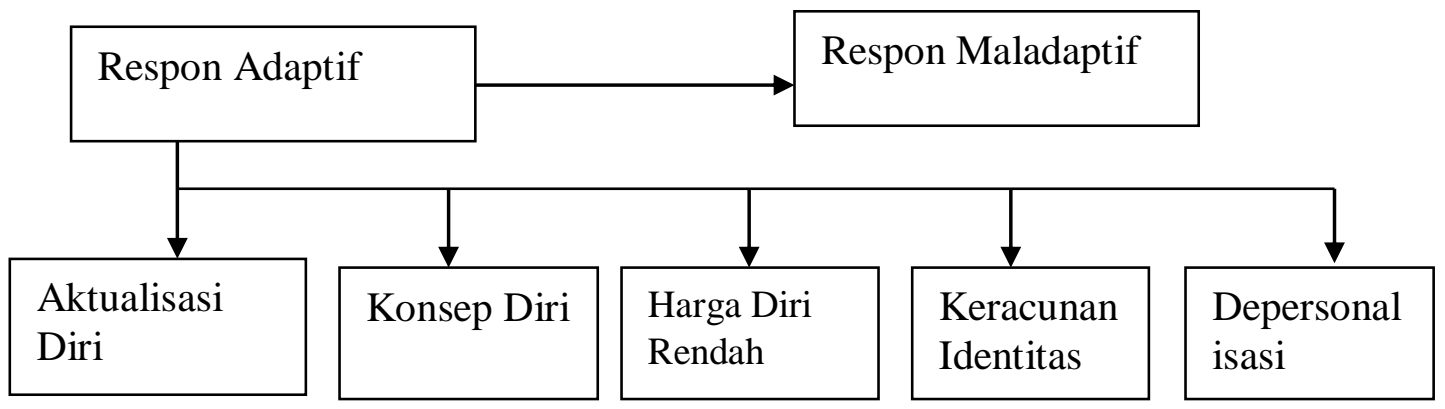

Keterangang :

1) Respon adaptif :

Aktualisasi diri dan konsep diri yang positif serta bersifat membangun (konstruksi) dalam usaha mengatasi stressor yang menyebabkan ketidakseimbangan dalam diri sendiri.

2) Respon maladaptif :

Aktualisasi diri dan konsep diri yang negatif serta bersifat merusak (destruktif) dalam usaha mengatasi stressor yang menyebabkan ketidakseimbangan dalam diri sendiri. 
3) Aktualisasi diri :

Respon adaptif yang tertinggi karena individu dapat mengekspresikan kemampuan yang dimilikinya.

4) Konsep diri positif :

Individu dapat mengidentifikasi kemampuan dan kelemahannya secara jujur dan dalam menilai suatu masalah individu berpikir secara positif dan realistis.

5) Harga diri rendahadalah individu yang cenderung untuk menilai dirinya yang negatif dan merasa lebih rendah dari orang lain.

6) Kekacauan identitas :

Suatu kegagalan individu untuk mengintegritasikan berbagai identifikasi masa kanak-kanak kedalam kepribadian psikososial dewasa yang harmonis.

7) Depersonalisasi :

Suatu perasaan yang tidak realistis dan keasingan dirinya dari lingkungan. Hal ini berhubungan dengan tingkat ansietas panik dan kegagalan dalam uji realitas. Individu mengalami kesulitan dalam membedakan diri sendiri dan orang lain dan tubuhnya sendiri terasa tidak nyata dan asing baginya.

\subsection{Manifestasi Klinis}

Menurut (Sitanggang, Pardede, Damanik, \& Simanullang, 2020) manifestasi klinis harga diri rendah yaitu :

1. Perasaan malu terhadap diri sendiri akibat adanya penyakit atau akibat tindakan terhadap penyakit

2. Rasa bersalah terhadap diri sendiri. Individu merasa tidak mampu dan tidak berguna dan memandang dirinya lemah

3. Gangguan hubungan sosial, seperti menarik diri dari masyarakat. Individu merasa tidak berguna sehingga klien merasa lebih suka menyendiri dan enggan untuk berinteraksi dengan lingkungan masyarakat 
4. Merendahkan martabat. Individu merasa dirinya lemah, merasa bodoh, merasa tidak mampu dalam melakukan segala hal, dan individu merasa tidak tahu apa - apa, mengabaikan, menolak kemampuan yang dimiliki sehingga produktivitas individu menurun

5. Percaya diri kurang. Individu merasa ragu - ragu dalam mengambil keputusan, individu tidak memiliki rasa percaya pada dirinya dan individu selalu memandang dirinya negatif

6. Mencederai diri sendiri dan orang lain. Akibat harga diri rendah individu memandang hidupnya pesimis, tidak berguna sehingga terdorong untuk merusak atau mengakhiri hidupnya. Bahkan klien dengan harga diri rendah timbul perasaan benci dan dapat menimbulkan perilaku kekerasan terhadap lingkungan sekitar.

\subsection{Mekanisme Koping}

Mekanisme koping termasuk pertahanan koping jangka panjang pendek atau jangka panjang serta penggunaan mekanisme pertahanann ego untuk melindungi diri sendiri dalam menghadapi persepsi diri yang menyakitkan (Eko, 2014). Pertahanan tersebut mencakup berikut ini :

Jangka pendek :

1. Aktivitas yang memberikan pelarian semestara dari krisis identitas diri ( misalnya, konser musik, bekerja keras, menonton tv secara obsesif)

2. Aktivitas yang memberikan identitas pengganti semestara ( misalnya, ikut serta dalam klub sosial, agama, politik, kelompok, gerakan, atau geng)

3. Aktivitas yang sementara menguatkan atau meningkatkan perasaan diri yang tidak menentu ( misalnya, olahraga yang kompetitif, prestasi akademik, kontes untuk mendapatkan popularitas)

Menurut (Sitanggang, Pardede, Damanik, \& Simanullang, 2020), pertahanan jangka panjang mencakup berikut ini : 
1. Penutupan identitas : adopsi identitas prematur yang diinginkan oleh orang terdekat tanpa memerhatikan keinginan,aspirasi,atau potensi diri individu

2. Identitas negatif : asumsi identitas yang tidak sesuai dengan nilai dan harapan yang diterima masyarakat.

3. Mekanisme pertahanan ego termasuk penggunaan fantasi, disosiasi,isolasi, proyeksi, pengalihan (displacement, berbalik marah terhadap diri sendiri, dan amuk).

\subsection{Penatalaksanaan}

Terapi pada gangguan jiwa skizofrenia dewasa ini sudah dikembangkan sehingga penderita tidak mengalami diskriminasi bahkan metodenya lebih manusiawi dari pada masa sebelumnya (Sitanggang, Pardede, Damanik, \& Simanullang, 2020), Terapi yang dimaksud meliputi :

1. Psikofarmaka

Berbagai jenis obat psikofarmaka yang beredar dipasaran yang hanya diperoleh dengan resep dokter, dapat dibagi dalam 2 golongan yaitu golongan generasi pertama (typical) dan golongan kedua (atypical). Obat yang termasuk golongan generasi pertama misalnya chlorpromazine HCL (psikotropik untuk menstabilkan senyawa otak), dan Haloperidol (mengobati kondisi gugup). Obat yang termasuk generasi kedua misalnya, Risperidone (untuk ansietas), Aripiprazole (untuk antipsikotik).

2. Psikoterapi

Terapi kerja baik sekali untuk mendorong penderita bergaul lagi dengan orang lain, penderita lain, perawat dan dokter, maksudnya supaya ia tidak mengasingkan diri lagi karena bila ia menarik diri ia dapat membentuk kebiasaan yang kurang baik. Dianjurkan untuk mengadakan permainan atau latihan bersama (Rokhimma \& Rahayu, 2020) 


\subsection{Konsep Asuhan Keperawatan}

Adapun konsep asuhan keperawatan harga diri rendah menurut Keliat (2016), adalah sebagai berikut :

\subsubsection{Pengkajian}

\section{Identifikasi klien}

1) Perawat yang merawat klien melakukan perkenalan dan kontrak dengan klien tentang: Nama klien, panggilan klien, Nama perawat, tujuan, waktu pertemuan, topik pembicaraan.

2) Keluhan utama / alasan masuk

a. Tanyakan pada keluarga / klien hal yang menyebabkan klien dan keluarga datang ke Rumah Sakit, yang telah dilakukan keluarga untuk mengatasi masalah dan perkembangan yang dicapai.

b. Tanyakan pada klien / keluarga, apakah klien pernah mengalami gangguan jiwa pada masa lalu, pernah melakukan, mengalami, penganiayaan fisik, seksual, penolakan dari lingkungan, kekerasan dalam keluarga dan tindakan kriminal.

2. Psikologis

Keluarga, pengasuh dan lingkungan klien sangat mempengaruhi respon psikologis dari klien.

3. Biologis

Gangguan perkembangan dan fungsi otak atau SSP, pertumbuhan dan perkembangan individu pada prenatal, neonatus dan anakanak.

4. Sosial Budaya

Seperti kemiskinan, konflik sosial budaya (peperangan, kerusuhan, kerawanan), kehidupan yang terisolasi serta stress yang menumpuk.

5. Aspek fisik / biologis 
Mengukur dan mengobservasi tanda-tanda vital: TD, nadi, suhu, pernafasan. Ukur tinggi badan dan berat badan, kalau perlu kaji fungsi organ kalau ada keluhan.

6. Aspek psikososial

1) Membuat genogram yang memuat paling sedikit tiga generasi yang dapat menggambarkan hubungan klien dan keluarga, masalah yang terkait dengan komunikasi, pengambilan keputusan dan pola asuh.

2) Konsep diri

a. Citra tubuh: mengenai persepsi klien terhadap tubuhnya, bagian yang disukai dan tidak disukai.

b. Identitas diri: status dan posisi klien sebelum dirawat, kepuasan klien terhadap status dan posisinya dan kepuasan klien sebagai laki-laki / perempuan.

c. Peran: tugas yang diemban dalam keluarga / kelompok dan masyarakat dan kemampuan klien dalam melaksanakan tugas tersebut.

d. Ideal diri: harapan terhadap tubuh, posisi, status, tugas, lingkungan dan penyakitnya.

e. Harga diri: hubungan klien dengan orang lain, penilaian dan penghargaan orang lain terhadap dirinya, biasanya terjadi pengungkapan kekecewaan terhadap dirinya sebagai wujud harga diri rendah.

3) Hubungan sosial dengan orang lain yang terdekat dalam kehidupan, kelompok yang diikuti dalam masyarakat.

4) Spiritual, mengenai nilai dan keyakinan dan kegiatan ibadah.

7. Status mental

Nilai penampilan klien rapi atau tidak, amati pembicaraan klien, aktivitas motorik klien, alam perasaan klien (sedih, takut, khawatir), afek klien, interaksi selama wawancara, persepsi klien, proses pikir, isi pikir, tingkat kesadaran, memori, tingkat 
konsentasi dan berhitung, kemampuan penilaian dan daya tilik diri.

8. Kebutuhan persiapan pulang

1) Kemampuan makan klien, klien mampu menyiapkan dan membersihkan alat makan.

2) Klien mampu $\mathrm{BAB}$ dan $\mathrm{BAK}$, menggunakan dan membersihkan WC serta membersihkan dan merapikan pakaian.

3) Mandi klien dengan cara berpakaian, observasi kebersihan tubuh klien.

4) Istirahat dan tidur klien, aktivitas di dalam dan di luar rumah.

5) Pantau penggunaan obat dan tanyakan reaksi yang dirasakan setelah minum obat.

9. Masalah psikososial dan lingkungan

Dari data keluarga atau klien mengenai masalah yang dimiliki klien.

10. Pengetahuan

Data didapatkan melalui wawancara dengan klien kemudian tiap bagian yang dimiliki klien disimpulkan dalam masalah.

11. Aspek medik

Terapi yang diterima oleh klien: ECT, terapi antara lain seperti terapi psikomotor, terapi tingkah laku, terapi keluarga, terapi spiritual, terapi okupasi, terapi lingkungan. Rehabilitasi sebagai suatu refungsionalisasi dan perkembangan klien supaya dapat melaksanakan sosialisasi secara wajar dalam kehidupan bermasyarakat.

12. Aktivitas dan istirahat

Gangguan tidur, bangun lebih awal, insomnia, dan hiperaktivitas.

13. Higiene

Kebersihan personal kurang, terlihat kusut/ tidak terpelihara.

14. Integritas ego 
1) Dapat timbul dengan ansietas berat, ketidakmampuan untuk rileks, kesulitan yang dibesar-besarkan, mudah agitasi.

2) Mengekspresikan persaaan tidak adekuat, perasaan tidak berharga, kurang diterima, dan kurang percaya pada orang lain. Menunjukkan kesulitan koping terhadap stres, menggunakan mekanisme koping yang tidak sesuai.

15. Neurosensori

Mengalami emosi dan perilaku abnormal dengan sistem keyakinan/ketakutan bahwa diri ataupun orang terdekat berada dalam bahaya karena diracuni atau diinfeksi, mempunyai penyakit, merasa tertipu oleh pasangan individu, dicurangi oleh orang lain, dicintai atau mencintai dari jarak jauh.

16. Keamanan

Dapat menimbulkan prilaku berbahaya/ menyerang

17. Interaksi sosial

1) Kerusakan bermakna dalam fungsi sosial/perkawinan

2) Umumnya bermasalah dengan hukum

\subsubsection{Diagnosa Keperawatan}

1. Isolasi sosial : menarik diri

2. Gangguan konsep diri : harga diri rendah

\subsubsection{Rencana Intervensi Keperawatan}

Adapun intervensi yang dapat dilakukan menurut Keliat (2014), yaitu :

\begin{tabular}{|c|c|l|}
\hline No. & \multicolumn{1}{|c|}{$\begin{array}{c}\text { Masalah } \\
\text { Keperawatan }\end{array}$} & \multicolumn{1}{|c|}{ Intervensi } \\
\hline 1. & $\begin{array}{l}\text { Isolasi sosial : } \\
\text { menarik diri }\end{array}$ & $\begin{array}{l}\text { SP 1 : } \\
\text { Menjelaskan keuntungan dan kerugian } \\
\text { mempunyai teman } \\
\end{array}$ \\
& & $\begin{array}{l}\text { SP 2 : } \\
\text { Melatih klien berkenalan dengan dua orang atau }\end{array}$ \\
\hline
\end{tabular}




\begin{tabular}{|c|c|c|}
\hline & & $\begin{array}{l}\text { lebih } \\
\text { SP 3 : } \\
\text { Melatih bercakap - cakap sambil melakukan } \\
\text { kegiatan harian } \\
\text { SP } 4 \text { : } \\
\text { Melatih berbicara sosial, meminta sesuatu, } \\
\text { berbelanja dan sebagainya }\end{array}$ \\
\hline 2. & $\begin{array}{l}\text { Gangguan } \\
\text { konsep diri : } \\
\text { harga diri } \\
\text { rendah kronis }\end{array}$ & $\begin{array}{l}\text { SP } 1 \text { : } \\
\text { Mengidentifikasi kemampuan dan aspek positif } \\
\text { yang dimiliki pasien } \\
\text { SP } 2 \text { : } \\
\text { 1) Menilai kemampuan yang dapat digunakan } \\
\text { 2) Menetapkan/ memilih kegiatan sesuai } \\
\quad \text { kemampuan. } \\
\text { 3) Melatih kegiatan sesuai kemampuan yang } \\
\text { SP } 3 \text { : } \\
\text { Melatih kegiatan sesuai kemampuan yang } \\
\text { dipilih } 2 \\
\text { SP } 4 \text { : } \\
\text { Melatih kegiatan sesuai kemampuan yang di } \\
\text { pilih } 3\end{array}$ \\
\hline
\end{tabular}

\subsubsection{Implementasi}

Menurut (Pardede, Keliat, \& Yulia, 2015), implementasi disesuaikan dengan rencana tindakan keperawatan. Pada situasi nyata sering pelaksanaan jauh berbeda dengan rencana, hal ini terjadi karena perawat belum terbiasa menggunakan rencana tertulis dalam melaksanakan tindakan keperawatan. Sebelum melaksanakan tindakan keperawatan yang sudah direncanakan, perawat perlu memvalidasi dengan singkat 
apakah rencana tindakan masih sesuai dan dibutuhkan klien sesuai dengan kondisinya (here and now). Perawat juga menilai diri sendiri, apakah kemampuan interpersonal, intelektual, tekhnikal sesuai dengan tindakan yang akan dilaksanakan, dinilai kembali apakah aman bagi klien. Setelah semuanya tidak ada hambatan maka tindakan keperawatan boleh dilaksanakan (Rokhimma \& Rahayu, 2020).

\subsubsection{Evaluasi}

Kemampuan yang diharapkan dari pasien menurut (Keliat, 2016), yaitu :

1. Pasien dapat mengungkapkan kemampuan dan aspek positif yang dimliki

2. Pasien dapat menilai kemampuan yang dapat dikerjakan

3. Pasien dapat melatih kemampuan yang dapat dikerjakan

4. Pasien dapat membuat jadwal kegiatan harian

5. Pasien dapat melakukan kegiatan sesuai jadwal kegaiatan harian 


\section{BAB 3}

\section{TINJAUAN KASUS}

\subsection{Identitas Klien}

$\begin{array}{ll}\text { Inisial } & : \text { Tn. A } \\ \text { Alamat Asal } & : \text { Kisaran } \\ \text { Tanggal Lahir } & : \text { 04 Oktober 1936 } \\ \text { Umur } & : \text { 85 Tahun } \\ \text { Agama } & : \text { Budha } \\ \text { Status } & : \text { Belum Menikah } \\ \text { Tanggal Pengkajian } & : \text { 04 Maret 2021 } \\ \text { Tanggal Masuk Yayasan } & : \text { 11 Agustus 2018 }\end{array}$

\subsection{Alasan Masuk Yayasan Pemenang Jiwa:}

Tn. A mengatakan bahwa dirinya di bawa ke yayayasan oleh cucu dari anak abangnya karena tidak ada yang menjaganya di rumah karena cucunya sibuk bekerja di luar kota. Tn. A mengatakan bahwa dia menderita penyakit epilepsi, sehingga kesulitan untuk berjalan.

\subsection{Faktor Predisposisi}

Tn. A mengatakan sudah 3 tahun dirawat di yayayasan dan belum bisa di izinkan pulang karena belum sembuh, apabila penyakit epilepsinya kambuh akan sangat berisiko bagi kesehatannya, sehingga pihak yayasan tidak mengizinkannya pulang. Tn.A juga mengatakan anggota keluarga yang lain tidak ada yang seperti dia yang mengalami gangguan jiwa.

Pengalaman masa lalu yang tidak menyenangkan:

Klien merasa sedih dan kecewa karena pernah ditinggal menikah oleh kekasihnya ketika masih berumur 25 tahun serta usaha restorannya bangkrut dan Tn. A merasa tidak berdaya dan mengatakan dunia tidak adil apalagi dulu 
pernah penyakit klien kambuh yaitu epilepsi didepan orang banyak, dan membuatnya sangat malu, sehingga membuat klien depresi/sakit kepala dan tidak dapat bekerja lagi

\subsection{Fisik}

Pada saat dilakukan pemeriksaan fisik pada pasien, pasien tidak memliki pemeriksaan fisik, didapat hasil :

1. Tanda Vital : $\mathrm{TD}=130 / 70 \mathrm{mmHg}, \mathrm{N}=80 \mathrm{x} / \mathrm{i}, \mathrm{S}=36,5^{\circ} \mathrm{C}, \mathrm{RR}$ $=20 \mathrm{x} / \mathrm{i}$

2. Ukur : $\mathrm{TB}=160 \mathrm{Cm}, \mathrm{BB}=60 \mathrm{Kg}$

3. Keluhan Fisik : Pada saat dilakukan pengkajian didapat bahwa Tn. A tidak mengalami keluhan fisik

\subsection{Psikososial}

\subsubsection{Genogram}

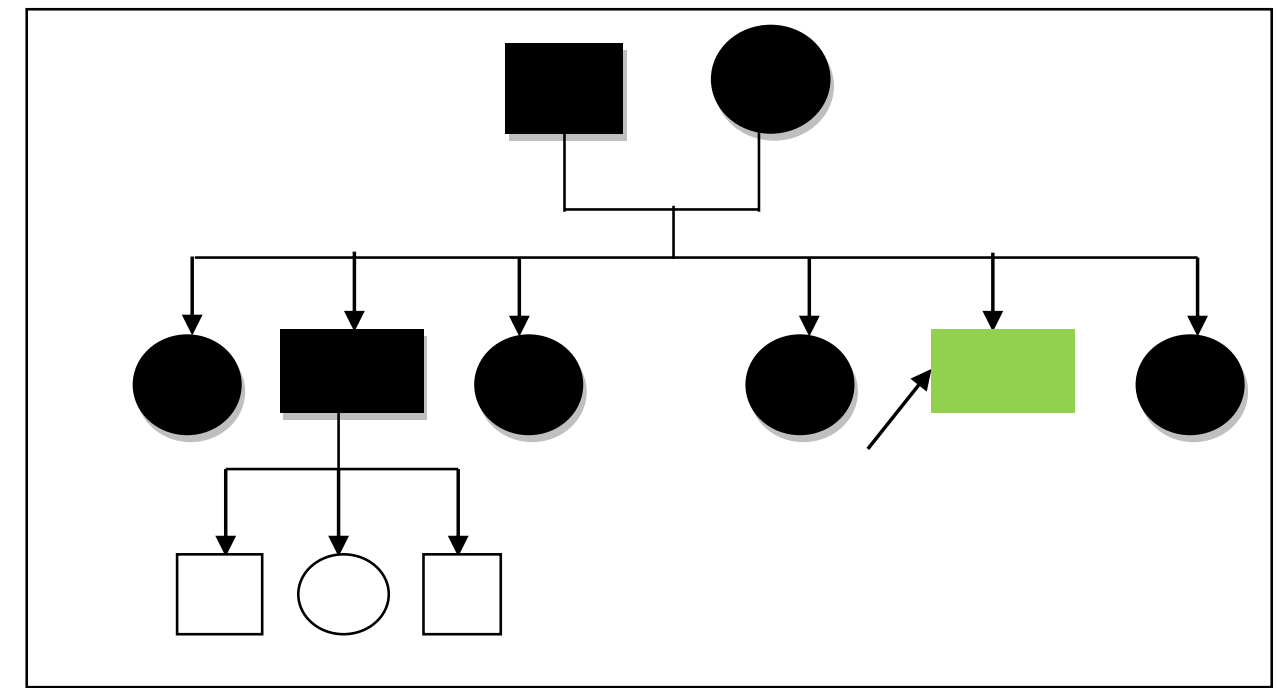

Keterangan :

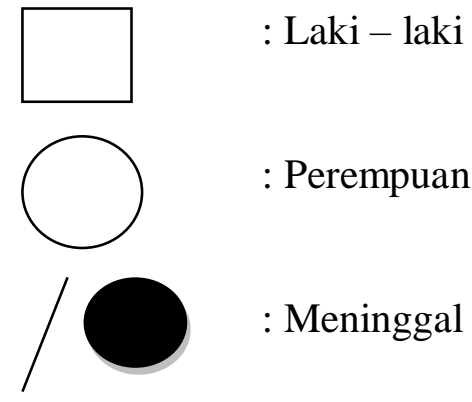



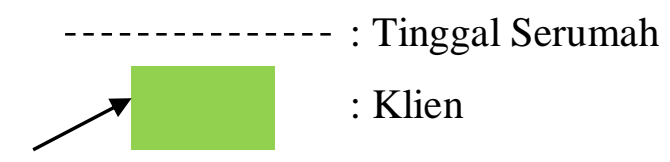

\subsubsection{Konsep Diri}

1. Gambaran

Diri

2. Identitas

3. Peran

4. Ideal Diri

5. Harga Diri
1. Klien merasa dirinya jelek karena tidak bisa berjalan tanpa bantuan kursi roda ataupun dipapah orang lain

2. Kecacatan atau kekurangan pada dirinya : Klien mengatakan saya adalah seorang koki dulu, karena sakit saya tidak bekerja lagi dan usaha saya bangkrut

3. Selama dirawat pasien berperan sebagai pasien dan sekarang klien tidak bisa bekerja dan beraktivitas seperti orang yang lainnya.

4. Jika saya sembuh nanti, saya akan menikmati masa tua saya dengan baik bersama cucu cucu saya anak

5. Saya merasa tidak dihargai dan disayangi karena cucu - cucu saya jarang datang untuk mengunjungi saya : Klien terlihat sedih, malu dengan keadaannya suara pelan, suka menyendiri, merasa di kucilkan karena penyakit yang dideritanya

Masalah Keperawatan : Harga diri rendah

\subsubsection{Hubungan sosial}

1. Orang yang berarti : Klien mengatakan bahwa dekat dengan pemilik yayasan karena mereka lebih memperhatikan klien

2. Peran serta dalam kegiatan kelompok/masyarakat : Pasien dalam kegiatan sehari-hari selalu aktif dan tidak menyendiri, pasien 
mampu berinteraksi dengan orang lain apabila orang lain duluan yang mengajaknya berbicara.

3. Hambatan dalam berhubungan dengan orang lain : Pasien merasa tidak diperhatian oleh keluarganya dan jarang dijenguk yaitu cucu - cucu nya, dan klien merasa di kucilkan karena penyakit epilepsi yang dideritanya.

\subsubsection{Spiritual}

1. Nilai dan Keyakinan : Klien merasa dirinya selalu dilindungi oleh Tuhan, klien selalu beribadah karena di Yayasan selalu mengutamakan untuk beribadah

2. Kegiatan ibadah : Ikut melakukan ibadah di yayasan setiap saat

\subsubsection{Status Mental}

1. Penampilan : Klien tampak berpakaian seperti biasanya

2. Pembicaraan : Klien ketika ditanya usia kadang menjawab 25 tahun kadang menjawab yang lain. Klien dapat berkomunikasi dengan baik, hanya saja Tn. A tidak mau memulai pembicaraan bila tidak dimulai duluan oleh orang lain dan klien merasa sedih jika dibicarakan mengenai cucu nya karena cucunya kurang perhatian terhadapnya karena sakitnya klien merasa tidak dihargai lagi.

Masalah Keperawatan : Harga diri rendah

3. Aktivitas motorik : saat diwawancara, klien merasa kurang semangat dan tegang.

4. Alam perasaan :Saat pengkajian klien mengatakan ingin sehat dan pulang untuk berkumpul bersama cucunya 
5. Afek : Jika di ajak bicara tentang yang menyenangkan maka ekspresinya senang, namun jika diajak berbicara yang sedih maka ekspresi nya akan sedih

6. Persepsi : Klien mengatakan bahwa sering mendengar suara suara seperti memanggil namanya saat klien sendirian, dan klien selalu menutup telinga nya saat suara itu muncul dan sering senyum - senyum sendiri dan bicara ngawur

\section{Masalah Keperawatan : Halusinasi pendengaran}

7. Proses Pikir : Klien selalu menjawab alasan masuk yayasan pemenang jiwa karena cucunya tidak menghargainya lagi dan tidak perhatian pada dirinya, dan cucunya lah yang memasukkannya ke yayasan, klien merasa dikucilkan, malu dengan penyakit yang di deritanya, sehingga membuatnya depresi.

Masalah Keperawatan : Harga diri rendah

8. Isi Pikir : Klien tidak menganggap dirinya secara berlebihan dan dapat menjelaskan tentang dirinya sesuai dengan kenyataan

9. Tingkat Kesadaran : Saat pengkajian klien sadar dan dapat menyebutkan nama, umur, dan lama rawatan di yayasan pemenang jiwa

10. Memori : Klien ingat semua tentang keluarganya dan kejadian saat dikaji

11. Tingkat Konsentrasi dan berhitung : Ketika dikaji klien dapat menjawab dengan fokus pertanyaan yang diberikan

12. Kemampuan penilaian : Klien mampu mengambil keputusan untuk mandi dulu lalu makan dengan alasan sesuai jadwal di yayasan pemenang jiwa

13. Daya tilik diri : Klien mengatakan dapat menerima dirinya yang sedang sakit, namun klien merasa dirinya tidak dihargai oleh 
cucunya dan tidak di perhatikan lagi karena cucunya jarang mengunjunginya

\subsubsection{Kegiatan yang dilakukan selama di yayasan}

1. Makan, minum, BAB/BAK

Pasien tidak dapat mengambil makan dan minum dan tidak dapat ke kamar mandi untuk BAB/BAK secara mandiri

2. Mandi, Berpakaian/berhias

Pasien mengatakan tidak dapat mandi dan berpakaian secara mandiri.

3. Istirahat dan tidur

Pasien tidur siang dari pukul $13.00 \mathrm{~s} / \mathrm{d} 15.00 \mathrm{WIB}$ dan tidur pada malam hari dari $22.00 \mathrm{~s} / \mathrm{d}$ 05.00 WIB. Kegiatan sebelum tidur dan sesudah makan adalah beribadah.

\subsection{Mekanisme Koping}

Klien mampu berbicara dengan orang lain, klien juga suka memijit orang lain pada saat orang lain mengajaknya berbicara duluan dan menyuruhnya memijat, namun saat tidak ada yang mengajak bicara duluan klien akan menyendiri dan tidak mau berinteraksi dengan orang lain.

Masalah Keperawatan : Isolasi Sosial

\subsection{Masalah Psikososial Dan Lingkungan}

1. Masalah dengan dukungan kelompok, sesifik: Pasien hanya melakukan kegiatan kelompok yang sudah direncanakan oleh perawat dan yayasan, diluar kegiatan itu hanya pasien habiskan di kamar dan tidur ataupun duduk bila tidak ada yang mengajak nya berbicara

2. Masalah dengan lingkungan : Klien sering ikut serta kegiatan diyayasan dan berkomunikasi dengan teman jika temannya duluan mengajaknya bebricara 
3. Masalah dengan pendidikan : Klien mengatakan pernah bersekolah tataboga

4. Masalah dengan pekerjaan : Klien sebelumnya pernah bekerja namun karena sakit dan bangkrut maka klien dibawa oleh cucunya ke yayasan pemenang jiwa klien ingin bekerja kembali sebagai seorang koki

5. Masalah dengan perumahan : Klien mengatakan pernah tinggal di rumah cucunya

6. Masalah dengan ekonomi : klien mengatakan tidak ada ada masalah dalam perekonomiannya karena saat ini seluruh biaya kebutuhannya cucunya yang membiayai

7. Masalah dengan pelayanan kesehatan :Klien tidak mengalami masalah dengan pelayanan kesehatan.

\subsection{Pengetahuan Kurang Tentang}

Klien mengatakan kurang tahu tentang keadaaannya saat ini karena klien merasa apa yang dilakukan itu benar

\subsection{Aspek Medik}

Diagnosa Medis : Harga Diri Rendah Kronis

Terapi Medik: Pedotoine 3x1

Depakute $250 \mathrm{mg} 3 \mathrm{x} 1$

\subsection{Analisa Data}

\begin{tabular}{|c|rc|l|}
\hline No. & Identifikasi Data & Masalah Keperawatan \\
\hline 1. & DS : & \\
& - & Klien merasa tidak dihargai dan tidak & Gangguan Konsep Diri : \\
& diperhatikan karena penyakitnya & Harga diri rendah kronis \\
& yang dideritanya yaitu epilepsi di & \\
\hline
\end{tabular}




\begin{tabular}{|c|c|c|c|}
\hline & $\begin{array}{r}\text { DO : } \\
\quad-\end{array}$ & $\begin{array}{l}\text { yayasan pemenang jiwa oleh cucunya } \\
\text { karena cucunya jarang berkunjung } \\
\text { Klien merasa minder dan malu karena } \\
\text { penyakit yang dideritanya } \\
\text { Klien tampak sedih, suara menjadi } \\
\text { pelan, kontak mata kurang }\end{array}$ & \\
\hline 2. & DS : & $\begin{array}{l}\text { Pegawai yayasan mengatakan klien } \\
\text { sering menyendiri } \\
\text { Klien tampak menyendiri, suka } \\
\text { menggaruk-garukkan tangannya } \\
\text { ketika diajak bicara } \\
\text { Menghindari kontak mata, } \\
\text { menghindari kontak mata, dan tidak } \\
\text { berani memulai pembicaraan }\end{array}$ & $\begin{array}{c}\text { Isolasi Sosial : Menarik } \\
\text { Diri }\end{array}$ \\
\hline 3. & $\begin{array}{r}\text { DS : } \\
- \\
- \\
- \\
- \\
\text { DO : } \\
-\end{array}$ & $\begin{array}{l}\text { Klien mengatakan sering mendengar } \\
\text { suara }- \text { suara yang memanggil } \\
\text { namanya namun orangnya tidak } \\
\text { terlihat } \\
\text { Klien merasa takut dan gelisah jika } \\
\text { mendengar suara itu muncul } \\
\text { Klien sering mendengar suara itu jika } \\
\text { klien sendirian } \\
\text { Klien menutup telinganya saat suara } \\
\text { itu datang memanggil namanya } \\
\text { Klien berbicara ngawur dan senyum - } \\
\text { senyum sendiri }\end{array}$ & $\begin{array}{c}\text { Gangguan Persepsi } \\
\text { Sensori: Halusinasi } \\
\text { Pendengaran }\end{array}$ \\
\hline
\end{tabular}




\subsection{Diagnosa Keperawatan}

1. Gangguan Konsep Diri : Harga diri rendah kronis

2. Isolasi Sosial : Menarik Diri

3. Gangguan Persepsi Sensori : Halusinasi Pendengaran

\section{Pohon masalah}

Gangguan persepsi halusinasi
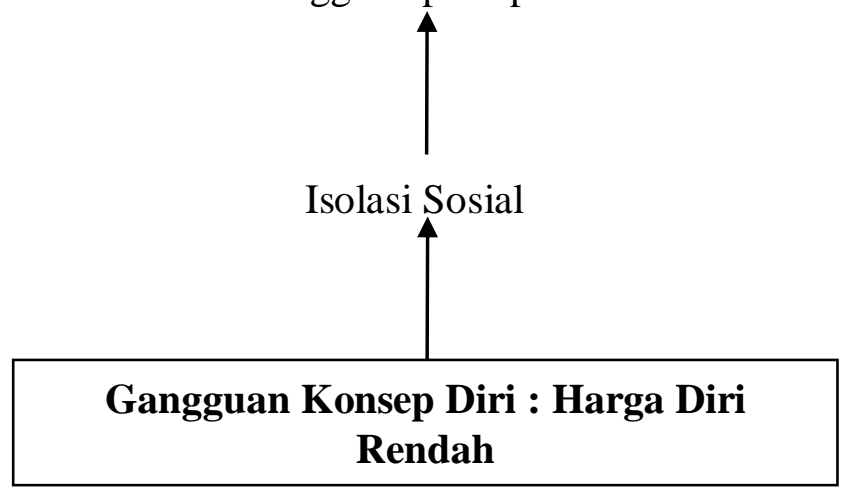

\subsection{Intervensi Keperawatan}

\begin{tabular}{|c|c|c|}
\hline No & Masalah Keperawatan & Intervensi \\
\hline \multirow{3}{*}{1.} & \multirow{3}{*}{$\begin{array}{c}\text { Gangguan Konsep Diri : Harga } \\
\text { diri rendah kronis }\end{array}$} & $\begin{array}{l}\text { SP1: } \\
\text { Mengidentifikasi kemampuan dan aspek } \\
\text { positif yang dimiliki pasien }\end{array}$ \\
\hline & & $\begin{array}{l}\text { SP2: } \\
\text { Menilai kemampuan yang dapat } \\
\text { digunakan menetapkan/ memilih } \\
\text { kegiatan sesuai kemampuan. Melatih } \\
\text { kegiatan sesuai kemampuan yang dipilih } \\
1\end{array}$ \\
\hline & & $\begin{array}{l}\text { SP3: } \\
\text { Melatih kegiatan sesuai kemampuan }\end{array}$ \\
\hline
\end{tabular}




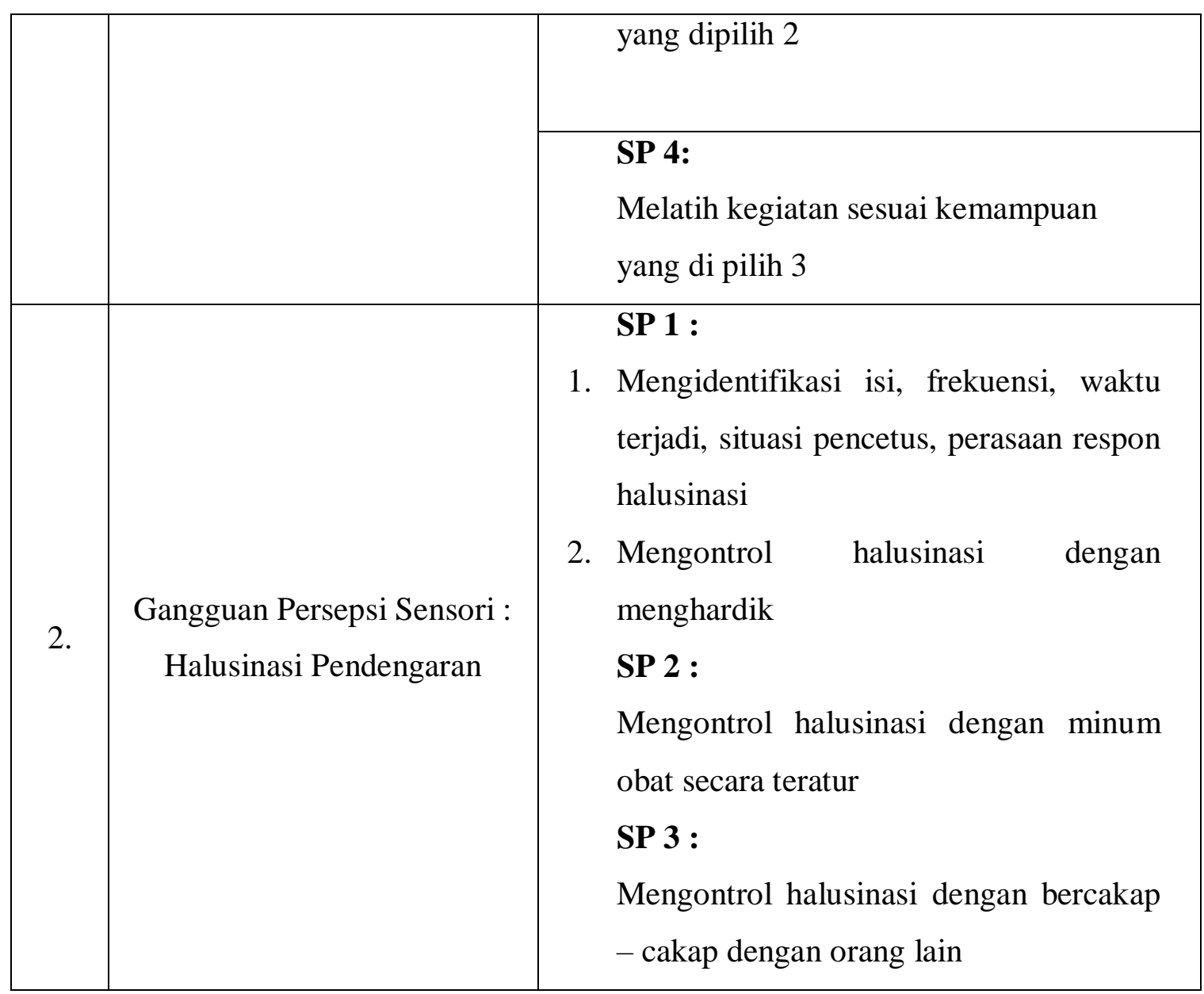

\subsection{Implementasi dan Evaluasi}

\begin{tabular}{|c|c|c|}
\hline $\begin{array}{c}\text { Hari / } \\
\text { Tgl }\end{array}$ & Implementasi & Evaluasi \\
\hline $\begin{array}{l}\text { Sabtu, } \\
\text { 06/ 03/ } \\
2021\end{array}$ & $\begin{array}{l}\text { Data } \\
\text { Tanda dan gejala : tidak mau } \\
\text { berbicara jika tidak ada yang duluan } \\
\text { mengajak bicara, wajah sedih, } \\
\text { murung, pendiam, malu pada } \\
\text { penyakitnya, dan suara pelan }\end{array}$ & $\begin{array}{l}\mathrm{S}: \text { Masih diam dan jika } \\
\text { ditanya atau diajak berbicara } \\
\text { masih lebih sering menunduk } \\
\text { kepala } \\
\mathrm{O}: \\
\text { Pasien belum } \\
\text { menunjukkan aspek positif } \\
\text { yang pasien miliki }\end{array}$ \\
\hline
\end{tabular}




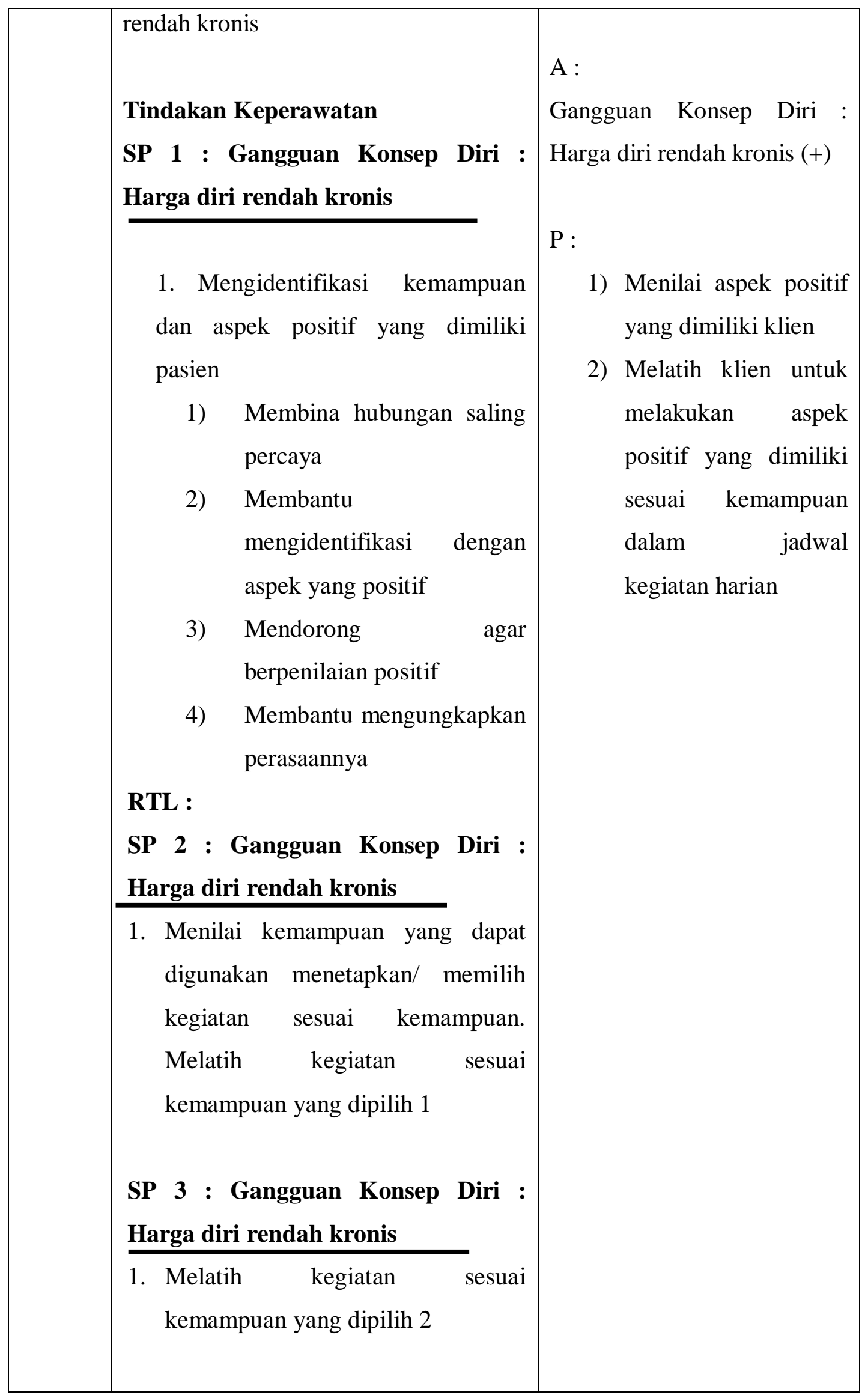




\begin{tabular}{|c|c|c|}
\hline & $\begin{array}{l}\text { SP } 4 \text { : Gangguan Konsep Diri : } \\
\text { Harga diri rendah kronis } \\
\text { Melatih kegiatan sesuai kemampuan } \\
\text { yang di pilih } 3\end{array}$ & \\
\hline $\begin{array}{l}\text { Rabu, } \\
10 / 03 / \\
2021\end{array}$ & 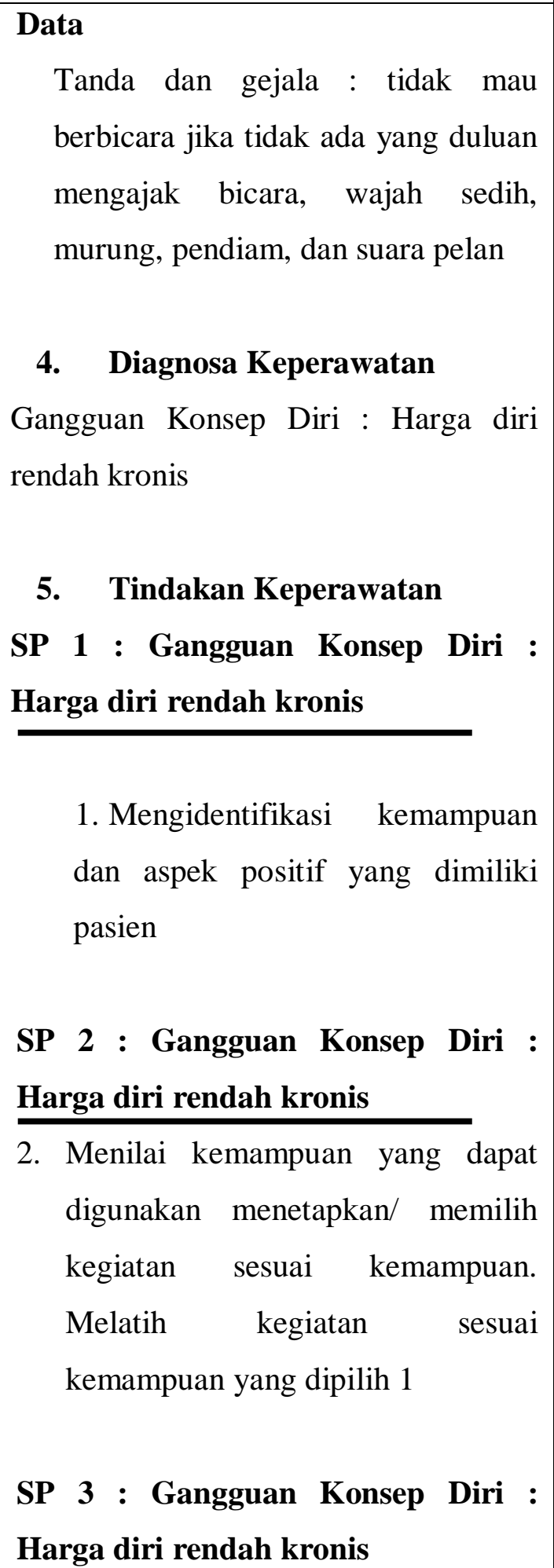 & $\begin{array}{l}\text { S : Pasien mulai bisa diajak } \\
\text { berbicara dan ngobrol } \\
\text { O : } \\
\text { Pasien mampu menjelaskan } \\
\text { hal-hal yang disukai dia } \\
\text { seperti : bernyanyi, memijit } \\
\text { dan mencicip rasa } \\
\text { A : } \\
\text { Gangguan Konsep Diri : } \\
\text { Harga diri rendah kronis (+) } \\
\text { P : Latihan Fisik } \\
\text { Melatih klien untuk } \\
\text { berinteraksi dengan orang } \\
\text { lain dengan cara memijat } \\
\text { temannya untuk mempererat } \\
\text { interaksi sosialnya sesuai } \\
\text { kemampuan positif yang } \\
\text { dimiliki }\end{array}$ \\
\hline
\end{tabular}




\begin{tabular}{|c|c|c|}
\hline & $\begin{array}{l}\text { 2. Melatih kegiatan sesuai } \\
\text { kemampuan yang dipilih } 2 \\
\text { SP } 4 \text { : Gangguan Konsep Diri : } \\
\text { Harga diri rendah kronis } \\
\text { Melatih kegiatan sesuai kemampuan } \\
\text { yang di pilih } 3 \\
\text { 6. } \\
\text { STL : } \\
\text { Harga diri rendah kronis } \\
\text { Melatih kegiatan sesuai kemampuan } \\
\text { yang di pilih } 3 \\
\text { - Klien dilatih cara meningkatkan } \\
\text { aspek positif yang dimilikinya }\end{array}$ & \\
\hline $\begin{array}{l}\text { Sabtu, } \\
\text { 13/ } 03 \text { / } \\
2021\end{array}$ & $\begin{array}{l}\text { 2. Diagnosa Keperawatan } \\
\text { Gangguan Konsep Diri : Harga diri } \\
\text { rendah kronis } \\
\text { 3. Tindakan Keperawatan } \\
\text { SP } 1 \text { : Gangguan Konsep Diri : } \\
\text { Harga diri rendah kronis } \\
\text { 1. Mengidentifikasi kemampuan } \\
\text { dan aspek positif yang dimiliki } \\
\text { pasien } \\
\text { SP } 2 \text { : Gangguan Konsep Diri : }\end{array}$ & $\begin{array}{l}\text { S : Senang dan bersemangat } \\
\text { O : } \\
\text { Klien mampu melakukan } \\
\text { aspek positif yang dimiliki } \\
\text { sesuai kemampuannya dan } \\
\text { mempraktekkannya dengan } \\
\text { baik } \\
\text { A : } \\
\text { Gangguan Konsep Diri : } \\
\text { Harga diri rendah kronis (+) }\end{array}$ \\
\hline
\end{tabular}




\begin{tabular}{|c|c|c|}
\hline & $\begin{array}{l}\text { Harga diri rendah kronis } \\
\text { 1. Menilai kemampuan yang dapat } \\
\text { digunakan menetapkan/ memilih } \\
\text { kegiatan sesuai kemampuan. } \\
\text { Melatih kegiatan sesuai } \\
\text { kemampuan yang dipilih } 1 \\
\text { SP } 3 \text { : Gangguan Konsep Diri : } \\
\text { Harga diri rendah kronis } \\
\text { 1. Melatih kegiatan } \\
\text { kemampuan yang dipilih } 2 \\
\text { SP } 4 \text { : Gangguan Konsep Diri : } \\
\text { Harga diri rendah kronis } \\
\text { Melatih kegiatan sesuai kemampuan } \\
\text { yang di pilih } 3 \\
\text { 4. RTL : } \\
\text { Gangguan Konsep Diri : Harga diri } \\
\text { rendah kronis ; Follow up dan evaluasi } \\
\text { Sp 1- } 4 \text { harga diri rendah }\end{array}$ & $\begin{array}{l}\text { positif yang dimiliki } \\
\text { klien } \\
\text { Latihan menilai } \\
\text { kegiatan yang sesuai } \\
\text { kemampuan dan } \\
\text { melatih kegiatan } \\
\text { sesuai kemampuan } \\
\text { yang di pilih 1 } \\
\text { Melatih kegiatan } \\
\text { sesuai kemampuan } \\
\text { yang dipilih } 2 \\
\text { Menyusun jadwal } \\
\text { untuk melakukan } \\
\text { kegiatan yang sudah } \\
\text { dilatih }\end{array}$ \\
\hline $\begin{array}{l}\text { Sabtu, } \\
10, \\
\text { Maret } \\
2021\end{array}$ & $\begin{array}{l}\text { 1. Data: } \\
\text { Tanda dan gejala : } \\
\text { pasien selalu menunduk dan tidak } \\
\text { mampu menjawab pertanyaan } \\
\text { yang diberikan dengan lancar } \\
\text { 2.Diagnosa Keperawatan Isolasi Sosial } \\
\text { 3. Tindakan keperawatan: } \\
\text { Sp 1 } \\
\text { Isolasi sosial : } \\
\text { - Mengidentifikasi } \\
\text { Harga diri penyebab } \\
\text { menanyakan rendahyaitu }\end{array}$ & 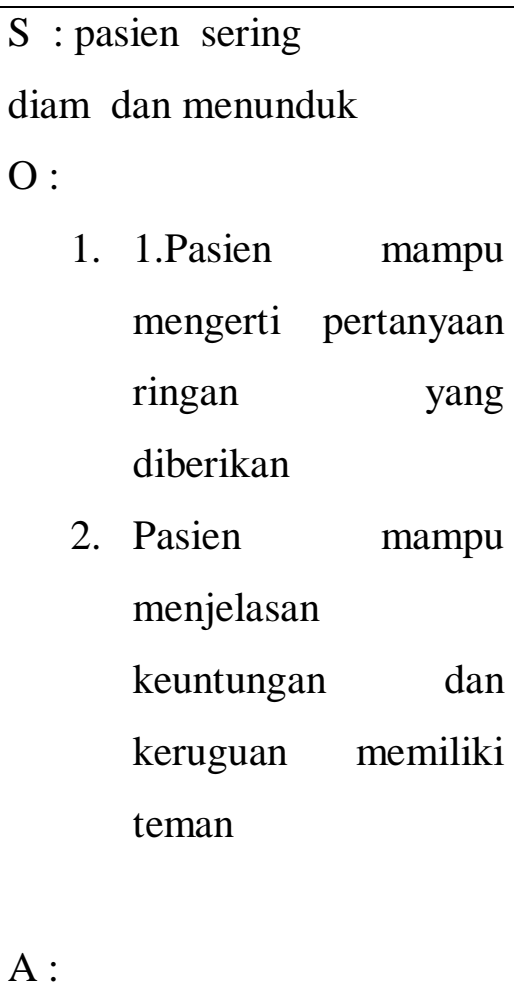 \\
\hline
\end{tabular}




\begin{tabular}{|c|c|c|}
\hline & $\begin{array}{l}\text { mengapa suka menunduk } \\
\text { - } \text { Mengidentifikasi tanda dan } \\
\text { gejala Harga diri rendah yaitu } \\
\text { - } \text { tidak lancar dalam bercakap - } \\
\text { cakap. } \\
\text { - Menjelaskan } \\
\text { dan kerugian mempunyai teman } \\
\text { 4. RTL: } \\
\text { Sp2 Isolasi sosial : } \\
\text { Melatih pasien berkenalan dengan } 2 \\
\text { orang atau lebih } \\
\text { SP 3: } \\
\text { Melatih bercakap-cakap } \\
\text { melakukan kegiatan harian: }\end{array}$ & $\begin{array}{l}\text { P : } \\
\text { Latihan fisik: } \\
\text { Melatih pasien berkenalan } \\
\text { dengan } 2 \text { orang atau lebih }\end{array}$ \\
\hline $\begin{array}{l}\text { Rabu, } \\
23 \\
\text { Maret } \\
2021\end{array}$ & $\begin{array}{l}\text { Data: } \\
\text { Tanda dan gejala : pasien selalu } \\
\text { menunduk dan tidak mampu } \\
\text { menjawab pertanyaan yang } \\
\text { diberikan dengan lancar } \\
\text { Diagnosa Keperawatan Isolasi Sosial } \\
\text { Tindakan keperawatan: } \\
\text { SP 2: } \\
\text { Melatih klien berkenalan dengan dua } \\
\text { orang atau lebih }\end{array}$ & $\begin{array}{l}\text { A : } \\
\text { Isolasi Sosial (+) } \\
\begin{array}{l}\text { P : } \\
\text { - } \text {-Latihan berkenalan } \\
\text { dengan dua orang } \\
\text { atau lebih 1x sehari } \\
-\quad \text { L Latihan }\end{array}\end{array}$ \\
\hline
\end{tabular}




\begin{tabular}{|l|l|lr|}
\hline Melatih bercakap - cakap sambal & komunikasi & secara \\
melakukan kegiatan harian : & verbal & asertif/ \\
& bicara & baik-baik \\
RTL: & $3 \mathrm{x} /$ hari. & \\
SP 4: & & \\
Melatih kegiatan sesuai kemampuan & & \\
yang dipilih 3 & & \\
\hline
\end{tabular}




\section{BAB 4}

\section{PEMBAHASAN}

Setelah mahasiwa melaksanakan asuhan keperawatan kepada Tn.A dengan Gangguan Konsep Diri : Harga diri rendah kronis di Yayasan pemenang jiwa Sumatera Utara, maka mahasiswa pada $\mathrm{BAB}$ ini akan membahas kesenjangan antara teoritis dan tinjauan kasus. Pembahasan dimulai melalui tahapan prosess keperatan yaitu pengkajian, diagnosa keperawatan, perencanaan, pelaksanaan dan evalusi

\subsection{Tahap Pengkajian}

Selama pengkajian dilakukan pengumpulan data dari beberapa sumber, yaitu dari pasien dan tenaga kesehatan di ruangan. Penulis mendapat sedikit kesulitan dalam menyimpulkan data karena keluarga pasien jarang mengunjungi pasien di yayasan pemenang jiwa. Maka penulis melakukan pendekatan kepada pasien melalui komunikasi teraupetik yang lebih terbuka membantu klien untuk memecahkan perasaannya dan juga melakukan observasi kepada pasien. Adapun upaya tersebut yaitu:

1. Melakukan pendekatan dan membina hubungan saling percaya diri pada klien agar klien lebih terbuka dan lebih percaya dengan menggunakan perasaan.

2. Mengadakan pengkajian klien dengan wawancara

3. Mengadakan pengkajian bertanya kepada pegawai yayasan pemenang jiwa.

Dalam pengkajian ini, penulis tidak menemukan kesenjangan karena ditemukan hal sama seperti diteori: Mengkritik diri sendiri, perasaan tidak mampu, pandangan hidup yang pesimis, penurunan produktivitas, penolakan terhadap kemampuan diri, malu terhadap diri sendiri, bicara ngawur, suka menyendiri, kontak mata kurang (Pardede, Keliat, Yulia, 2020). 


\subsection{Tahap perencanaan}

Perencanaan dalam proses keperawatan lebih dikenal dengan rencana asuhan keperawatan yang merupakan tahap selanjutnya setelah pangkajian dan penentuan diagnosa keperawatan. Pada tahap perencanaan penulis hanya menyusun rencana tindakan keperawatan sesuai dengan pohon masalah keperawatan yaitu : Gangguan Konsep Diri : Harga diri rendah kronis (Keliat 2016).

Pada tahap ini antara tinjauan teoritis dan tinjauan kasus tidak ada kesenjangan sehingga penulis dapat melaksanakan tindakan seoptimal mungkin dan didukung dengan tersedianya sarana ruangan perawat yang baik dan adanya bimbingan dan petunjuk dari petugas kesehatan dari rumah sakit jiwa yang diberikan kepada penulis. Secara teoritis digunakan cara strategi pertemuan sesuai dengan diagnosa keperawatan yang muncul saat pengkajian. Adapun upaya yang dilakukan penulis yaitu :

Gangguan Konsep Diri : Harga diri rendah kronis

1) Mengidentifikasi penyebab waham

2) Mengidentifikasi tanda dan gejala harga diri rendah

3) Mengidentifikasi akibat waham

4) Membantu pasien mempraktekkan Latihan orienatsi realitas: orientasi orang,waktu tempat dan lingkungan sekitar

5) Menjelaskan dan mengingatkan untuk minum oba secara teratur

6) Membantu pasien mempraktekkan cara pemenuhan kebutuhan dasar

7) Membantu pasien melatih kemampua positif yang positif

8) Mengevaluasi jadwal kegiatan harian pasien

\subsection{Tahap Implementasi}

Pada tahap implementasi mahasiswa hanya mengatasi masalah keperawatan dengan diagnosa keperawatan Gangguan Konsep Diri : Harga diri rendah kronis. Pada diagnosa keperawatan Gangguan Konsep Diri : Harga diri 
rendah kronis dilakukan strategi pertemuan yaitu mengidentifikasi kemampuan dan aspek positif yang dimiliki pasien, menilai kemampuan yang dapat digunakan menetapkan/ memilih kegiatan sesuai kemampuan "melatih kegiatan sesuai kemampuan yang dipilih 1", melatih kegiatan sesuai kemampuan yang dpilih 2, dan melatih kegiatan sesuai kemampuan yang di pilih 3 (Pardede, Keliat, \& Yulia, 2015).

\subsection{Tahap evaluasi}

Pada tinjauan kasus evaluasi yang dihasilkan adalah :

1) Klien sudah dapat mengidentifikasi kemampuan dan aspek positif yang dimiliki

2) Klien dapat menilai kemampuan yang dapat digunakan menetapkan/ memilih kegiatan sesuai kemampuan "melatih kegiatan sesuai kemampuan yang dipilih 1 "

3) Klien dapat melatih kegiatan sesuai kemampuan yang dpilih 2

4) Klien dapat melatih kegiatan sesuai kemampuan yang di pilih 3. 


\section{BAB 5}

\section{PENUTUP}

\subsection{Kesimpulan}

Setelah menguraikan tentang proses keperawatan pada Tn. A dan disimpulkan bahwa pasien dapat mengidentifikasi kemampuan dan aspek positif yang dimiliki dengan terapi yang di ajarkan oleh mahasiwa. Dimana pasien dapat melakukan kegiatan sesuai kemampuannya.

\subsection{Saran}

1. Diharapkan pada keluarga sering mengunjungi pasien selama waktu perawatan karena dengan seringnya keluarga berkunjung, maka pasien merasa berarti dan dibutuhkan dan juga setelah pulang keluarga harus memperhatikan obat dikonsumsi seta membawa pasien kontrol secara teratur kepelayana kesehatan jiwa ataupun rumah sakit jiwa.

2. Bagi mahasiswa/ mahasiswi agar lebih memperdalam ilmu pengetahuan khusus tentang keperawatan jiwa. 


\section{DAFTAR PUSTAKA}

1. Eko, Prabowo. (2014). Konsep dan Aplikasi Asuhan Keperawatan Jiwa. Penerbit : Nuha - Medika

2. Keliat, B. A. (2016). Keperawatan Kesehatan Jiwa Komunitas. Jakarta : EGC

3. Keliat, B. A.(2014). Model Praktik Keperawatan Profesional Jiwa. EGC : Jakarta

4. Kemenkes RI.(2019). Riset Kesehatan Dasar, RISKESDAS. Jakarta: Kemenkes

https://databoks.katadata.co.id/datapublish/2019/10/08/persebaranprevalensi-skizofreniapsikosis-di-indonesia

5. Muhith, A. (2015). Pendidikan Keperawatan Jiwa Teori dan Aplikasi. (M.Bendetu,Ed.) (1sted.).Yogyakarta: CV Andi Offset. https://books.google.co.id

6. Pardede, J. A. (2019). Health Education of Drinking Medication Adherence on Schizophrenia Patients. Journal of Psychiatry, 2(2), 723.

7. Pardede, J. A, Keliat, B. A, \& Yulia, I. (2015). Kepatuhan dan Komitmen Klien Skizofrenia Meningkat Setelah Diberikan Acceptanse And Commitment Therapy dan Pendidikan Kesehatan Kepatuhan Minum Obat. Jurnal Keperawatan Indonesia, 18 (3), 157-166 http://jki.ui.ac.id/index.php/jki/article/view/419

8. Pardede, J. A., Keliat, B. A., \& Wardani, I. Y. (2020). The Symptoms of Low Self-Esteem Decline after Being Given Acceptance and Commitment $\begin{array}{llll}\text { Therapy. Adv Practice } & \text { Nurs, } 5, & \end{array}$ https://www.hilarispublisher.com/open-access/the-symptoms-of-low selfesteem-decline-after-being-given-acceptance-and-commitment therapy.pdf

9. Pardede, J. A., Ariyo, A., \& Purba, J. M. (2020). Self Efficacy Related to Family Stress in Schizophrenia Patients. Jurnal Keperawatan, 12(4), 831838.

http://www.journal.stikeskendal.ac.id/index.php/Keperawatan/article/view $\underline{1010}$

10. Pardede, J. A., Harjuliska, H., \& Ramadia, A. (2021). Self-Efficacy dan Peran Keluarga Berhubungan dengan Frekuensi Kekambuhan Pasien Skizofrenia. Jurnal Ilmu Keperawatan Jiwa, 4(1), 57-66. https://journal.ppnijateng.org/index.php/jikj/article/view/846

11. Rokhimmah, Y., \& Rahayu, D. A. (2020). Penurunan Harga Diri Rendah dengan menggunakan Penerapan Terapi Okupasi (Berkebun). Journal Ners Muda, 1(1), 18. https://doi.org/10.26714/nm.v1i1.5493 
12. Septina. (2020). Asuhan Keperawatan Pada Klien Skizofrenia Dengan Masalah Harga Diri Rendah Kronik (Doctoral dissertation, Universitas Muhammadiyah Ponorogo). http://eprints.umpo.ac.id/6116/

13. Sitanggang, R., Pardede, J. A., Damanik, R. K., \& Simanullang, R. H. (2020). The Effect Of Cognitive Therapy On Changes In Self-Esteem On Schizophrenia Patients. European Journal of Molecular \& Clinical Medicine, 11 (7), 2515-8260 https://ejmcm.com/article_6267.html

14. Wandono, W. A., \& Arum Pratiwi, S. (2017). Upaya peningkatan harga diri rendah pada pasien depresi (Doctoral dissertation, Universitas Muhammadiyah Surakarta). http://eprints.ums.ac.id/id/eprint/52383

15. Yusuf, A dkk. (2015). Buku Ajar Keperawatan Kesehatan Jiwa. Jakarta Salemba Medika. http://eprints.umpo.ac.id/6107/ 